\title{
Men's Knowledge and Attitudes Towards Breast Cancer: A Descriptive Study
}

\author{
Ayşe Nilüfer Özaydın ${ }^{1}$ (D), Emrah Doğan ${ }^{1}$ (D), Berk Bozdoğan² \\ ${ }^{1}$ Department of Public Health, Marmara University School of Medicine, İstanbul, Turkey \\ ${ }^{2}$ Marmara University School of Medicine, İstanbul, Turkey
}

\begin{abstract}
Objective: Breast cancer (BC) is an important disease for women. BC influences both patient's and relatives' lives. Especially, husbands/boyfriends/ lovers are the ones that are affected mostly. In this study, it was aimed to introduce knowledge and attitudes of men toward $\mathrm{BC}$ and their sources of information about BC.

Materials and Methods: This descriptive study was conducted with men applied to a University Hospital in Istanbul (Turkey-2018). The ethics permission was obtained from The Clinical Research Ethics Committee. Data regarding socio-demographic characteristics with the knowledge and attitudes towards BC were collected with a questionnaire specific to the research. Statistical significance level was accepted as $\mathrm{p}<0.05$.

Results: In the study, 240 men (mean age: $36.2 \pm 10.6$ years,min: 18.0, max: 63.0) were interviewed. Fifty four percent of men declared that they would not marry someone with $\mathrm{BC}$ and/or someone who had mastectomy. Thirty four percent of participants thought that a woman with BC should conceal the disease. The mean BC knowledge score was 234.1 128.0 (median: 227.5, min: 0, max: 571.0) among the total which was 600.

Conclusion: A significant proportion of men did not have sufficient and accurate knowledge about $\mathrm{BC}$. If the BC knowledge scores increase, there was an association with more positive attitudes. Negative attitudes of men related with BC of a woman may be an indicator of stigmatization. If it is aimed to increase support of men for women dealing with $\mathrm{BC}$, it is recommended that $\mathrm{BC}$ awareness activities should be prepared to include men in order to increase their knowledge and to change their attitudes into a more positive way.

Keywords: Sexual partner, sexuality, fertility, education
\end{abstract}

Cite this articles as: Özaydın AN, Doğan E, Bozdoğan B. Men’s Knowledge and Attitudes Towards Breast Cancer: A Descriptive Study. Eur J Breast Health 2020; 16(3): 183-191.

\section{Introduction}

Cancer is one of major cause of morbidity and mortality worldwide (1). According to the reports of The International Agency for Research on Cancer (IARC), 12.7 million people were estimated to receive a new cancer diagnosis globally in 2008, but this number increased to 18.1 million people in 2018 (2,3). Fifty seven percent of the new cancer cases and 65\% of people who lost their lives because of cancer are in the developing countries, such as Turkey. This indicates that cancer is an important public health problem in developing countries too (4).

Breast cancer $(11.9 \%)$ is the second most common cancer following the lung cancer (13\%) worldwide (1). Breast cancer is by far the most frequently diagnosed cancer and cause of cancer death among women. According to latest estimates of IARC (2018), breast cancer constitutes $24.2 \%$ of all female cancers (about one fourth of all new cancer cases in females worldwide are breast cancer) and is the leading cause of cancer death in females (15\%). Breast cancer incidence is higher than other cancer incidences in both developed and developing countries (3).

In Turkey, the incidence of breast cancer (age-standardised rate, ASR) was 31.9/100.000 in 2002, and it has increased to 43.8/100.000 (ASR) in 2015. Currently, breast cancer is the most common cancer among women in Turkey (24.7\%) (5). While it is in the first place among female cancers in age groups " $25-49$ years", "50-69 years" and " $\geq 70$ ", in age group " $15-24$ years" it is placed in $6^{\text {th }}$ place (respectively $34.1 \%, 25.5 \%, 15.2 \%$ and $4.5 \%)(6)$. 
In addition to the early diagnosis of breast cancer, early access to treatment and early start-up of treatment are crucial. However, the aim of the treatments should be achievement of complete physical, mental and social well-being and not merely absence of disease or infirmity (7). Thanks to the advances in today's medicine, physical well-being in breast cancer is firstly tried to be provided with medicines, surgeries, and mental well-being is provided with psychiatric support when it is necessary. Social well-being, which is another component of full wellbeing, is influenced by many cultural and economic factors belonging to the individual, family and society (8).

In social and daily life, "female body and sexuality" are constructed and reproduced by cultural and social elements. The factors such as beauty, glamour and temptation imposed on the female body cause the woman to be seen as a sexual object. When the woman, who is seen as a sexual object, loses her breast due to mastectomy she has, she perceives this as a loss of femininity, fertility, attractiveness and sexuality. This damage in the body image of the woman can cause various psychosocial problems. The problem here is that, because of the sexist attitude towards women, the woman herself and her body are seen as the source of seduction, temptation and shame $(9,10)$.

The value, respectability or acceptability among her peers or in her society of a woman is measured with the degree of sexual attraction of her body in modern societies. Because the capitalist consumer market and the culture it creates have standardized the female body. The bodies that are out of the norm are described as inferior, disgusting and unkempt. Such bodies are considered as a category that should not be present in interpersonal areas (on the street, in the workplace, in peer groups, near spouses or lovers, on special occasions) (9). It is known that these thoughts are established in the society and that after the diagnosis of cancer, the patient herself, her family and spouses' experiences difficulties and these difficulties may result in divorces (11-13). This situation arouses curiosity about attitudes of men towards breast cancer which is the most common female cancer in Turkey.

Despite extensive research on breast cancer, authors have had difficulty in accessing researches in the English literature in which attitudes and knowledge of men towards breast cancer are assessed. Also, in the

\section{Key Points}

- Breast cancer is the most incident cancer among women. Not only effects women, but also people around them. Despite the establishment of effect of men on the health of women, men seem to have a small share of the effort made in breast cancer researches.

- Men have a great and important place in women's lives and are dominant on women's life choices. On account of that, the knowledge and the attitude of men towards breast cancer should be assessed carefully.

- It has been shown that breast health occupies a large and important area in the decision making of men about woman.

- The breast cancer knowledge score the knowledge score and positive attitudes were directly proportional. This shows that efforts to increase knowledge level of the men would effects women health in a positive manner.

- In this descriptive study, authors tried to establish some main points which thought to be related with attitudes of men towards breast cancer. Since the reasons of the attitudes and opinions were not areas of interest of this study, designing and conducting qualitative studies to reveal the background of this area are strongly recommended.
Table 1. Socio-demographic characteristics of participants

$\begin{array}{lll}\text { Socio-demographic characteristics } & \mathbf{n} & \% \\ \begin{array}{l}\text { Age Groups (Year) } \\ \leq 29\end{array} & 73 & 30.4 \\ 30-39 & 94 & 39.2 \\ 40-49 & 41 & 17.1 \\ \geq 50 & 32 & 13.3\end{array}$

Marital Status

Married 159

Divorced/Separated/Widowed/Living together 18

Never married

Education

Illiterate/Literate/Primary School

Middle School

High School

University and higher degree(s)

Income (\$)*

According to Monthly Income

$\leq 1603$ (267.6)

1604-3206 (267.7-535.2)

3207-4809 (535.4-802.8)

$\geq 4810$ (803)

According to Hunger Threshold

$$
\leq 1857 \text { (310) }
$$

$\geq 1858$ (310.2)

According to Poverty Threshold

$$
\leq 6424 \text { (1072.4) }
$$

$\geq 6425$ (1072.6)

Having Children** $(n=177)$

Yes

$143 \quad 80.8$

No

Having a Relative with Breast Cancer

Yes

Kinship to the Individual with Cancer

$\begin{array}{lcc}\text { Mother } & 6 & 33.3 \\ \text { Sister } & 4 & 22.2 \\ \text { Wife } & 8 & 44.4 \\ \text { Total } & 240 & 100.0\end{array}$

The Central Bank of Turkey, 2018 September 28. Available from: URL: http://www.tcmb.gov.tr/kurlar/201809/28092018.xml

* It was changed from Turkish Liras to USD with indicative exchanges rates announced by the Central

**Participants who had never experienced marriage were not included 
Turkish literature, researchers could not source any research about this subject. It is aimed in this article to shed light on subjects of knowledge and attitudes of men towards breast cancer and their sources of information about breast cancer.

\section{Materials and Methods}

This is a descriptive study. It was conducted in Marmara University Hospital in Istanbul, Turkey in September-October 2018. The ethics permission was obtained from Marmara University School of Medicine Clinical Research Ethics Committee (September 02, 2018, protocol no: 09.2018.611), all participants were informed and their consents were obtained.

For the study, a special questionnaire was developed by the researchers: A preliminary test was conducted and then the necessary questions were revised. The questionnaire consisted of 48 questions in total. The first part was 8 questions about the socio-demographic characteristics of the participants and the next 32 questions were specific questions to assess the knowledge about breast cancer. In these questions, the correct and incorrect answers were scored and a "total breast cancer knowledge score" was calculated (max: 600, min: 0). There were also 7 questions about attitude of participants toward breast cancer and 1 more question was sources of breast cancer information of participants.

Due to the challenges of being in a hospital environment, the volunteer participants were interviewed face to face and their answers were recorded.

\section{Statistical analysis}

Data from the study were analyzed in Statistical Package for the Social Sciences (SPSS 11.0, IBM Corp.; Armonk, NY, USA) programme. Normality test, Student's T-test, Chi-Square test, correlation tests were performed and $\mathrm{p}<0.05$ was accepted for the statistical significance level.

\section{Results}

In this study, 240 volunteer males were interviewed. The mean age of the participants was $36.2 \pm 10.6$ years (median: 36.0 , min: 18.0 max: 63.0). $70.4 \%$ of the participants were graduated from high school and

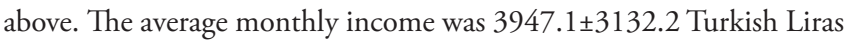
(median: 3000.0, min: 800, max: 30.000). Socio-demographic characteristics of the participants are presented in Table 1.

Table 2. Breast cancer knowledge score distribution of men according to some basic characteristics

\begin{tabular}{|c|c|c|c|c|c|c|c|}
\hline \multirow{2}{*}{$\begin{array}{l}\text { Socio-demographic } \\
\text { characteristics }\end{array}$} & \multicolumn{6}{|c|}{ Knowledge Score of Breast Cancer } & \multirow[b]{2}{*}{$\mathbf{p}$} \\
\hline & $\mathbf{n}$ & Mean & SD & Median & Min. & Max. & \\
\hline \multicolumn{8}{|l|}{ Age Groups(Year) } \\
\hline$\leq 29$ & 73 & 239.3 & 151.5 & 210.0 & 0 & 570.0 & 0.574 \\
\hline $30-39$ & 94 & 221.4 & 109.4 & 220.0 & 0 & 460.0 & \\
\hline $40-49$ & 41 & 236.9 & 138.2 & 230.0 & 30.0 & 535.0 & \\
\hline$\geq 50$ & 32 & 255.9 & 106.6 & 275.0 & 40.0 & 520.0 & \\
\hline \multicolumn{8}{|l|}{ Education } \\
\hline Illiterate/Literate/Primary School & 38 & 200.4 & 124.3 & 200.0 & 20.0 & 500.0 & 0.002 \\
\hline Middle School & 33 & 189.7 & 107.9 & 190.0 & 0.0 & 470.0 & \\
\hline High School & 92 & 226.3 & 131.9 & 215.0 & 0.0 & 570.0 & \\
\hline University and higher degree(s) & 77 & 279.0 & 121.4 & 295.0 & 30.0 & 535.0 & \\
\hline \multicolumn{8}{|l|}{ Monthly Income (\$) } \\
\hline \multicolumn{8}{|l|}{ (According to Poverty Threshold) } \\
\hline$\leq 1072.4$ & 213 & 227.3 & 126.9 & 220.0 & 0.0 & 570.0 & 0.020 \\
\hline$\geq 1072.6$ & 27 & 287.9 & 125.8 & 270.0 & 60.0 & 525.0 & \\
\hline \multicolumn{8}{|l|}{ Marital Status } \\
\hline Married & 159 & 225.5 & 117.3 & 220.0 & 0.0 & 535.0 & 0.381 \\
\hline Divorced/Separated/Widowed/Living together & 18 & 224.2 & 125.2 & 230.0 & 60.0 & 520.0 & \\
\hline Never married & 63 & 258.7 & 151.6 & 250.0 & 10.0 & 570.0 & \\
\hline \multicolumn{8}{|l|}{ Having Children (n:177) } \\
\hline Yes & 143 & 237.5 & 115.4 & 240.0 & 0.0 & 535.0 & 0.004 \\
\hline No & 34 & 174.1 & 115.2 & 170.0 & 0.0 & 460.0 & \\
\hline \multicolumn{8}{|l|}{ Having a Relative with Breast Cancer } \\
\hline Yes & 18 & 202.2 & 151.3 & 155.0 & 40.0 & 505.0 & 0.273 \\
\hline No & 222 & 236.7 & 125.9 & 230.0 & 0.0 & 570.0 & \\
\hline
\end{tabular}




\section{Breast cancer knowledge scores}

The knowledge score of males was assessed with a questionnaire developed by researchers. According to this form, the mean score was 234.1 \pm 128.0 (median: 227.5, min: 0, max: 571.0). The distribution of knowledge scores according to socio-demographic characteristics of men is shown in Table 2 .

\section{Table 3. The declared attitudes of men about breast cancer}

\section{Attitude Questions \\ Would you marry someone with breast cancer?}

No. I would not

I do not know

Yes. I would

$110 \quad 45.8$

Would you marry someone who had a mastectomy?

No

I do not know

Yes

What would you do if your wife was diagnosed with breast cancer?

I would consider divorce.

It's none of my business. I'm going back to where I left off.

I don't know what to say right now.

I would support her and fight together to cure the disease.

What would you do if your wife had a mastectomy?

I would consider divorce.

It's none of my business. I would go back to where I left off.

I don't know what to say right now.

I would try to give her support and comfort.

If your wife had a mastectomy and she wanted breast reconstruction surgery, what would be your attitude?

I would oppose

It would not matter

I don't know what to say right now.

I would encourage her

$93 \quad 38.8$

If your wife/spouse/mother had breast cancer, would you conceal it from other people?

Yes

I do not know

No

$151 \quad 62.9$

Should a woman with breast cancer conceal her disease?

$$
\text { Yes }
$$

I do not know

No

$158 \quad 65.8$

Total

240100.0

\section{Attitude assessment}

Results of the participants' attitudes towards breast cancer are given in Table 3.

Eighty one percent of men who thought that breast cancer would affect fertility of woman and $94.0 \%$ of men who thought that breast cancer would not affect fertility said that they would support their wives if their wives had breast cancer (p:0.016) (Table 4).

Eighty four percent of the men who have children said that they would support their wives if they had mastectomy. On the other hand, $67.6 \%$ of men who do not have children said that they would support their wives if they had a mastectomy (p:0.03) (Table 5).

In addition to the results presented in the tables, some of the important findings are given in the following paragraphs.

While $5 \%$ of participants who had not any spouse or first degree relative with breast cancer said that "A woman should conceal that she has breast cancer", none of the participants with a spouse or first degree relative with breast cancer agreed with this idea $(p>0.05)$.

While only $40.6 \%$ of men who were 50 years and older stated that they could marry someone with breast cancer, nearly half of (47.9\%) $\leq 29$ age group stated that they could marry someone with breast cancer $(\mathrm{p}>0.05)$.

Fifty one percent of university graduates and $39.4 \%$ of middle school graduates stated that they could marry someone with breast cancer (p: 0.068).

While $50.8 \%$ of men who never married said that they could marry someone with breast cancer, only $33.3 \%$ of men with marriage experience said they could marry someone with breast cancer $(p>0.05)$.

While $63 \%$ of those whose income status is above the "poverty threshold" stated that they could marry a person with breast cancer, this ratio was $43.7 \%$ of those below the poverty threshold ( $>0.05$ ).

Only $55.6 \%$ of males with any breast cancer cases in their family and $45 \%$ of those without breast cancer cases in their family said that they could marry someone with breast cancer (p:0.02).

While $52.1 \%$ of participants under 29 years of age declared that they could marry someone who had a mastectomy, this ratio was $40.6 \%$ in the $\geq 50$ age group (p:0.019).

Eighty five percent of participants who thought that sexual life of a woman with breast cancer would be impaired and $92,0 \%$ of those who thought it would not be impaired stated that they would support their wives (p:0.014).

Breast cancer knowledge scores of participants who stated that they would support their wives were significantly higher than those who would not support their wives [respectively 254.1 \pm 124.9 (median: 250.0, min: 0, max: 570.0) and 136.8 \pm 95.1 (median: 110.0, min: 10.0, max: 360.0)] (p: 0.0001), if their wives were diagnosed with breast cancer.

Similar to previous results, breast cancer knowledge scores of participants who stated that they would support their wives were significantly higher than those who would not support their wives [respectively $263.4 \pm 116.3$ (median: 280.0, min: 0, max: 520.0) and 215.5 \pm 131.9 (median: 200.0, min: 0, max: 570.0)] (p: 0.004), if their wives had a mastectomy. 
Information source of participants

The participants' sources of information were questioned and results were presented in Table 6.
The mean breast cancer knowledge score of participants whose source

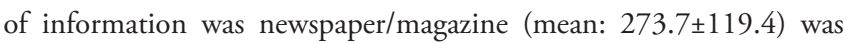
higher than those whose source of information was not newspaper/

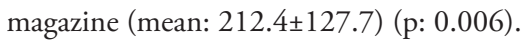

Table 4. The distribution of the situation of supportiveness of men, when their wives had breast cancer

\begin{tabular}{|c|c|c|c|c|c|c|c|}
\hline \multirow[b]{3}{*}{ Socio-demographic Characteristics } & \multicolumn{6}{|c|}{$\begin{array}{l}\text { What would a man do if their wives } \\
\text { were diagnosed with breast cancer? }\end{array}$} & \multirow[b]{3}{*}{$\mathbf{p}$} \\
\hline & \multicolumn{2}{|c|}{ Would Support } & \multicolumn{2}{|c|}{ Would Not Support } & \multicolumn{2}{|c|}{ Total } & \\
\hline & $\mathbf{n}$ & $\%$ & $\mathbf{n}$ & $\%$ & $\mathbf{n}$ & $\%$ & \\
\hline \multicolumn{8}{|l|}{ Age Groups (Year) } \\
\hline$\leq 29$ & 58 & 79.5 & 15 & 20.5 & 73 & 100.0 & 0.820 \\
\hline $30-39$ & 79 & 84.0 & 15 & 16.0 & 94 & 100.0 & \\
\hline $40-49$ & 35 & 85.4 & 6 & 14.6 & 41 & 100.0 & \\
\hline$\geq 50$ & 27 & 84.4 & 5 & 15.6 & 32 & 100.0 & \\
\hline \multicolumn{8}{|l|}{ Education } \\
\hline Illiterate/Literate/Primary School & 31 & 81.6 & 7 & 18.4 & 38 & 100.0 & 0.399 \\
\hline Middle School & 25 & 75.8 & 8 & 24.2 & 33 & 100.0 & \\
\hline High School & 75 & 81.5 & 17 & 18.5 & 92 & 100.0 & \\
\hline University and higher degree(s) & 68 & 88.3 & 9 & 11.7 & 77 & 100.0 & \\
\hline \multicolumn{8}{|l|}{ Monthly Income (\$)(According to Poverty Threshold) } \\
\hline$\leq 1072.4$ & 175 & 82.2 & 38 & 17.8 & 213 & 100.0 & 0.284 \\
\hline$\geq 1072.6$ & 24 & 88.9 & 3 & 11.1 & 27 & 100.0 & \\
\hline \multicolumn{8}{|l|}{ Marital Status } \\
\hline Married & 130 & 81.8 & 29 & 18.2 & 159 & 100.0 & 0.779 \\
\hline Divorced/Separated/Widowed/Living together & 15 & 83.3 & 3 & 16.7 & 18 & 100.0 & \\
\hline Never married & 54 & 85.7 & 9 & 14.3 & 63 & 100.0 & \\
\hline \multicolumn{8}{|l|}{ Having Children } \\
\hline Yes & 121 & 84.6 & 22 & 15.4 & 143 & 100.0 & 0.053 \\
\hline No & 24 & 70.6 & 10 & 29.4 & 34 & 100.0 & \\
\hline \multicolumn{8}{|l|}{ Having a Relative with Breast Cancer } \\
\hline Yes & 14 & 77.8 & 4 & 22.2 & 18 & 100.0 & 0.370 \\
\hline No & 185 & 83.3 & 37 & 16.7 & 222 & 100.0 & \\
\hline \multicolumn{8}{|l|}{ Breast Cancer Disturbs a Woman's Sexual Life } \\
\hline No & 80 & 90.9 & 8 & 9.1 & 88 & 100.0 & 0.014 \\
\hline I do not know & 79 & 75.2 & 26 & 24.8 & 105 & 100.0 & \\
\hline Yes & 40 & 85.1 & 7 & 14.9 & 47 & 100.0 & \\
\hline \multicolumn{8}{|l|}{ Breast Cancer Affects Woman's Fertility } \\
\hline No & 63 & 94.0 & 4 & 6.0 & 67 & 100.0 & 0.016 \\
\hline I do not know & 107 & 78.1 & 30 & 21.9 & 137 & 100.0 & \\
\hline Yes & 29 & 80.6 & 7 & 19.4 & 36 & 100.0 & \\
\hline \multicolumn{8}{|l|}{ Breast Cancer Knowledge Score } \\
\hline$\leq 200$ & 72 & 69.2 & 32 & 30.8 & 104 & 100.0 & 0.0001 \\
\hline $201-400$ & 106 & 92.2 & 9 & 7.8 & 115 & 100.0 & \\
\hline$\geq 401$ & 21 & 100.0 & 0 & 0.0 & 21 & 100.0 & \\
\hline Total & 199 & 82.9 & 4 & 17.1 & 240 & 100.0 & \\
\hline
\end{tabular}


Table 5. The distribution of the situation of supportiveness of men, when their wives had a mastectomy

\begin{tabular}{|c|c|c|c|c|c|c|c|}
\hline \multirow[b]{3}{*}{ Socio-demographic Characteristics } & \multicolumn{6}{|c|}{$\begin{array}{l}\text { What would a man do if their } \\
\text { wives had mastectomy? }\end{array}$} & \multirow[b]{3}{*}{$\mathbf{p}$} \\
\hline & \multicolumn{2}{|c|}{ Would Support } & \multicolumn{2}{|c|}{ Would Not Support } & \multicolumn{2}{|c|}{ Total } & \\
\hline & $\mathbf{n}$ & $\%$ & $\mathbf{n}$ & $\%$ & n & $\%$ & \\
\hline \multicolumn{8}{|l|}{ Age Groups (Year) } \\
\hline$\leq 29$ & 58 & 79.5 & 15 & 20.5 & 73 & 100.0 & 0.827 \\
\hline $30-39$ & 79 & 84.0 & 15 & 16.0 & 94 & 100.0 & \\
\hline $40-49$ & 35 & 85.4 & 6 & 14.6 & 41 & 100.0 & \\
\hline$\geq 50$ & 26 & 81.2 & 6 & 18.8 & 32 & 100.0 & \\
\hline \multicolumn{8}{|l|}{ Education } \\
\hline Illiterate/Literate/Primary School & 30 & 78.9 & 8 & 21.1 & 38 & 100.0 & 0.753 \\
\hline Middle School & 26 & 78.8 & 7 & 21.2 & 33 & 100.0 & \\
\hline High School & 76 & 82.6 & 16 & 17.4 & 92 & 100.0 & \\
\hline University and higher degree(s) & 66 & 85.7 & 11 & 14.3 & 77 & 100.0 & \\
\hline \multicolumn{8}{|l|}{ Monthly Income (\$)(According to Poverty Threshold) } \\
\hline$\leq 1072.4$ & 174 & 81.7 & 39 & 18.3 & 213 & 100.0 & * \\
\hline$\geq 1072.6$ & 24 & 88.9 & 3 & 11.1 & 27 & 100.0 & \\
\hline \multicolumn{8}{|l|}{ Marital Status } \\
\hline Married & 128 & 80.5 & 31 & 19.5 & 159 & 100.0 & 0.483 \\
\hline Divorced/Separated/Widowed/Living together & 15 & 83.3 & 3 & 16.7 & 18 & 100.0 & \\
\hline Never married & 55 & 87.3 & 8 & 12.7 & 63 & 100.0 & \\
\hline \multicolumn{8}{|l|}{ Having Children (n:177) } \\
\hline Yes & 120 & 83.9 & 23 & 16.1 & 143 & 100.0 & 0.03 \\
\hline No & 23 & 67.6 & 11 & 32.4 & 34 & 100.0 & \\
\hline \multicolumn{8}{|l|}{ Having a Relative with Breast Cancer } \\
\hline Yes & 14 & 77.8 & 4 & 22.2 & 18 & 100.0 & * \\
\hline No & 184 & 82.9 & 38 & 17.1 & 222 & 100.0 & \\
\hline \multicolumn{8}{|l|}{ Breast Cancer Disturbs a Woman's Sexual Life } \\
\hline No & 80 & 90.9 & 8 & 9.1 & 88 & 100.0 & 0.004 \\
\hline I do not know & 77 & 73.3 & 28 & 26.7 & 105 & 100.0 & \\
\hline Yes & 41 & 87.2 & 6 & 12.8 & 47 & 100.0 & \\
\hline \multicolumn{8}{|l|}{ Breast Cancer Affects Woman's Fertility } \\
\hline No & 63 & 94.0 & 4 & 6.0 & 67 & 100.0 & 0.006 \\
\hline I do not know & 106 & 77.4 & 31 & 22.6 & 137 & 100.0 & \\
\hline Yes & 29 & 80.6 & 7 & 19.4 & 36 & 100.0 & \\
\hline \multicolumn{8}{|l|}{ Breast Cancer Knowledge Score } \\
\hline$\leq 200$ & 71 & 68.3 & 33 & 31.7 & 104 & 100.0 & 0.0001 ** \\
\hline $201-400$ & 106 & 92.2 & 9 & 7.8 & 115 & 100.0 & \\
\hline$\geq 401$ & 21 & 100.0 & 0 & 0.0 & 21 & 100.0 & \\
\hline Total & 198 & 82.5 & 42 & 17.5 & 240 & 100.0 & \\
\hline
\end{tabular}




\section{Table 6. Information sources of men related to breast cancer}

\begin{tabular}{lcc|}
\hline Information source* & n & \% \\
\hline TV & 127 & 52.9 \\
Physicians & 92 & 38.3 \\
Newspapers and magazines & 85 & 35.4 \\
Friends. relatives and neighbours & 67 & 27.9 \\
Advertisement & 54 & 22.5 \\
Brochure & 54 & 22.5 \\
Nurses & 37 & 15.4 \\
\hline *More than one answer was acceptable & & \\
\hline
\end{tabular}

The mean breast cancer knowledge score of men who stated that they

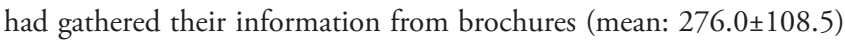

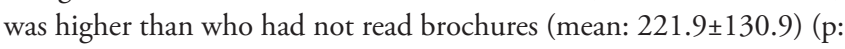
0.006).

The mean knowledge score of participants who said they had been informed by a doctor (mean: $254.9 \pm 134.6)$ was higher than who had not been informed by a doctor (p: 0.047).

\section{Discussion and Conclusion}

Breast cancer is ranked first among female cancers and is one of the most important diseases for women in Turkey as well as in the world. While breast cancer is in the first place among female cancers in age groups " $25-49$ years", " $50-69$ years" and " $\geq 70$ ", in the age group " 15 24 years" it is placed in 6th place (respectively $34.1 \%, 25.5 \%, 15.2 \%$ and $4.5 \%)(6)$. When women are diagnosed with this disease, they are mostly in the reproductive age, where they may be married and/ or engaged and/or have a boyfriend. Not only the organ in which the disease is seen is perceived as a mere body part, but also is perceived by both men and women as a special organ for female sexuality in many different cultures and societies (14). This approach affects both attendance of women's screening for early diagnosis and causes psychosocial problems after treatment (12). The target group of studies related with breast cancer is mostly women, since breast cancer is mostly seen in women. Few studies which evaluate the knowledge, attitudes and behaviors of men with women in their lives during breast cancer diagnosis and treatment have been reached. In order to shed light on the subject scientifically, this study was planned and data was collected successfully. This study, when conducted with men who have applied to a university hospital and who have voluntarily participated in the study, is one of the pioneering studies in this field of research. Although, breast cancer is the most important disease for females, authors have had difficulty in accessing studies for comparison that evaluate knowledge and attitudes of men towards breast cancer in English literature. Unfortunately, no other published article in the Turkish literature could be reached.

In our study, $54.2 \%$ of men declared that they would not marry someone that had breast cancer and/or someone whose breast(s) had been removed. In our study, questions regarding the reasons for this situation were not asked. The authors thought that this is an important area of interest and strongly recommended that qualitative studies should be conducted to find the reason: men do not want to marry as to whether she is not healthy or whether she is not considered attractive anymore.

Thirty four percent of our participants thought that a woman with breast cancer should conceal her disease. Although, details about the reason(s) for this opinion could not be obtained, it may be related with the perception of the breast mainly as a sexual organ. Because of this, it is seen as an inappropriate subject to talk about by society. Since it is accepted as a sexual organ, people, both men and women, in Turkey prefer to use the word "chest" instead of "breast". Also, the reason might be related with the fear of cancer and its consequences, such as death.

In our study, if wives of the participants were diagnosed with breast cancer, $82.9 \%$ of men stated that they would support their wives, $11.7 \%$ were undecided and only $3.3 \%$ declared that they would think of divorce. In a study conducted in Saudi Arabia, 90.6\% of men stated that they would never leave their wives if they were diagnosed with breast cancer, while 9.4\% said they would leave. However, despite this finding, researchers from Saudi Arabia emphasized that this may not be the case when it comes to reality (15). Similarly, we believe that if a study was conducted in a specific population who had breast cancer cases it may reflect a more realistic situation. Fear of being abandoned by husbands or partners of women may affect negatively the behaviors of women to attend breast cancer screening programmes.

An interesting finding in our study is that the knowledge of breast cancer in men of different age groups was similar. However, it was found that the knowledge of breast cancer was significantly higher in males with children than those without any children. In our study, the knowledge of men about breast cancer was positively affected by being educated at high school and above, having higher income from poverty threshold and having children, but the age, marital status and having any relatives with breast cancer did not affect their breast cancer knowledge scores.

In our study, the breast cancer knowledge of men who had any relative with breast cancer did not show any difference compared to those without any relative with breast cancer. The reason(s) behind this has aroused curiosity. Do men not try to obtain information about disease of their relatives or do they avoid communication with the person who has breast cancer because the breast is perceived as a sexual organ?

While $85.1 \%$ of the men who thought that the sexual life of a woman with breast cancer would be deteriorated declared that they would support their wives if women are diagnosed with breast cancer, $91 \%$ of the men who did not think this way declared they would support their wives. Eighty one percent of the participants who believed that breast cancer would affect a woman's fertility said that they would support their wives in case of a breast cancer diagnosis, this ratio was $94.0 \%$ in men who did not believe breast cancer would affect a woman's fertility.

In our study group it was found there was a directly proportional relationship between education level and breast cancer knowledge scores of the participants. Similar relationship was also found between breast cancer knowledge scores and positive attitudes in the breast cancer diagnosis and mastectomy situations. However, there was not any significant relationship between education level and positive attitudes of men. It is unknown as to why positive attitudes were observed with extreme high scores such as $\geq 401$ points and scores which were completely independent of the education level. This important result may shed light on the necessity and the importance of the breast cancer awareness activities specifically designed for the men. 
It has been thought that the health of the breast, which generally is considered as a sexual organ of women, is seen an important criterion for marriage by our participants. In addition to this, it is thought that sexuality and fertility are important criteria for man in marriage. In case of a negative health status stemming from women in these subjects, lack of support of the men may affect both women's health and the couples' marriage in a negative way.

Until International Conference on Population and Development-1994, men had not been considered as a target group for reproductive health issues and no awareness activities for men were conducted. In this conference, it was accepted that one of the biggest reasons of the lack of expected effects of different interventions at national and / or international level in order to increase the reproductive health status in a society would be the exclusion of men in this field, and after 1994, reproductive health services have been given in a holistic approach which included both sexes from birth to death $(16,17)$. As a disease, breast cancer mostly occurs in the female body, however, it is a chronic disease which affects life of patients and their families in terms of physical and psychiatric well-being. Therefore, it is recommended to carry out similar holistic approaches in breast cancer activities to enhance knowledge and attitude of men and women positively.

The men who participated in our study stated that they obtained their knowledge about breast cancer most often from TV programmes, physicians and newspapers/magazines respectively. Similar to our findings, it was reported that males used TV/radio, newspapers/magazines and doctors/nurses as their source of information respectively (18). In a study, men's major sources of information were physicians, internet and the media (15). Another study parallel to our findings, TV and newspapers represented major sources of information for men (19).

It is a limitation that this study could be conducted with only voluntary participants who were relatives of patients who applied to hospital for any complaint. It is recommended to conduct a research in a larger sample group that can be more representative of the Turkish society. Due to lack of a specific attitude scale in this area, attitude questions were developed by the researchers. It is recommended to researchers working in this field, that there is a need to produce a standardized attitude scale. In addition, due to the importance and characteristics of the subject, it is considered and suggested that it should be evaluated together with a gender attitude scale.

In conclusion, when the attitudes of men towards women with breast cancer are questioned, more than half of the participants declared that they would not marry a woman with breast cancer and/or who had mastectomy, while the majority of men stated that if their wife was diagnosed with breast cancer they would support her, and only $3 \%$ of the men reported that they would get divorced from their wives. However, with a hypothetical questioning, the possibility of responding in favour of social expectations should be kept in mind, and it should be taken into consideration that their behavior may be very different in the case of 'real life'. One in ten men stated that if his wife's breast had to be removed, he was undecided about whether or not to leave, which could in fact be regarded as a sincere and open confession.

In order to change the attitudes of men on these issues in a positive way, it is necessary to demolish the stereotypes and transfer the correct information to all men by media. By developing positive attitudes of men, early and effective participation of women in diagnosis and be prevented. Therefore, it is recommended the organization of breast cancer awareness activities which is not only targeted at healthy/diseased women, but also for men.

Ethics Committee Approval: Ethics committee approval was received for this study from Marmara University School of Medicine Clinical Research Ethics Committee (September 02, 2018, protocol no: 09.2018.611).

Informed Consent: Written informed consent was obtained from all participants' themselves who participated in this study.

Peer-review: Externally peer-reviewed.

Author Contributions: Concept - A.N.Ö., E.D., B.B.; Design - A.N.Ö., E.D., B.B.; Supervision - A.N.Ö., E.D., B.B.; Resources - A.N.Ö.; Materials - A.N.Ö., E.D., B.B.; Data Collection and/or Processing - A.N.Ö., E.D.; Analysis and/or Interpretation - A.N.Ö., B.B.; Literature Search - A.N.Ö., E.D., B.B.; Writing Manuscript - A.N.Ö., B.B.; Critical Review - A.N.Ö., E.D., B.B.

Acknowledgements: Authors would like to thank Dr. Abdullah Mercan, Dr. Ali Nofal, Dr. Bahadır Emre Soylu, Dr. Osman Çolak and all the voluntary participants.

Conflict of Interest: The authors have no conflicts of interest to declare.

Financial Disclosure: The authors declared that this study has received no financial support.

\section{References}

1. Stewart BW, Wild CP, editors. World cancer report 2014. Lyon: IARC; 2014. ISBN 978-92-832-0429-9.

2. Boyle P, Levin B, editors. World cancer report 2008. Lyon; IARC; 2008. ISBN 978-92-832-0423-7.

3. The International Agency for Research on Cancer. Latest global cancer data: Cancer burden rises to 18.1 million new cases and 9.6 million cancer deaths in 2018. Press Release No: 263 2018. (cited 2019 July 25). Available from: URL:https://www.iarc.fr/wp-content/uploads/2018/09/ pr263_E.pdf.

4. Ozmen V, editor. Breast cancer in Turkey. Turkey: Cinius; 2017. ISBN 978-605-296-077-6.

5. Bora Başara B, Soytutan Çağlar İ, Aygün A, Özdemir TA, editors, General Directorate of Health Information Systems, Ministry of Health. Health Statistics Yearbook 2017. Ankara; 2018. (cited 2019 July 25). Available from: URL:https://dosyasb.saglik.gov.tr/Eklenti/30148,ingilizcesiydijiv1 pdf.pdf?0.

6. Sencan I, Keskinkilic B, editors, Public Health Institution of Turkey, Ministry of Health.Turkey Cancer Statistics. Ankara; 2017. (cited 2019 July 25). Available from: URL:https://hsgm.saglik.gov.tr/depo/birimler/ kanser-db/istatistik/2014-RAPOR._uzuuun.pdf.

7. World Health Organization. Basic documents-48th ed. WHO; 2014. ISBN 9789241650489 (cited 2019 July 25). Available from: URL:http://apps.who.int/gb/bd/PDF/bd48/basic-documents-48th-edition-en.pdf\#page=1.

8. Akin A, editor. Toplumsal cinsiyet, sağlık, kadın. Hacettepe University; 2003. ISBN: 975-491-141-X.

9. Bilgin R. Body and sexuality of women in traditional and modern society. Firat Univ J Social Sci 2016; 26: 219-243. [CrossRef]

10. Çavdar İ. Sexual problems of the patients who suffer from breast carcinoma. Eur J Breast Health 2006; 2: 64-66.

11. Woloski-Wruble AC, Ganz FD, Jiang Y, Qiang W, Kadmon I. Israeli and Chinese partners of women with breast cancer: a cross-cultural view of marital issues. Psycho-oncology 2012; 21: 324- 331. (PMID: 22383274) [CrossRef] 


\section{Özaydın et al. Men's Attitudes Towards Breast}

12. Babacan Gumus A. Psychosocial issues in breast cancer and supportive interventions. Eur J Breast Health 2006; 2: 108-114.

13. Bahar S. Hastalıktan geriye kalan tarifsiz acı terk eden kocalar. Economics News, Sabah Gazetesi; 2018. (cited 2019 July 25). Available from: URL:https://www.sabah.com.tr/ekonomi/2018/06/24/hastaliktan-geriye-kalan-tarifsiz-aci-terk-eden-kocalar.

14. Denizgil T, Sonmez I. Comparison of self esteem, body image, sexual satisfaction and sexual experiences between women who had mastectomy or breast conserving surgery for breast carcinoma. Yeni Symposium 2015; 53: 17-25.

15. Al-Amoudi SM, Abduljabbar HS. Men's knowledge and attitude towards breast cancer in Saudi Arabia: a cross-sectional study. Saudi Med J 2012; 33: 547-550. (PMID: 22588817)

16. United Nations [Internet]. New York (NY): UN. Report of the International Conference on Population and Development, Cairo, 5-13 Septem- ber 1994 1995. (cited 2019 July 25). Available from: https://www.unfpa. org/sites/default/files/event-pdf/icpd_eng_2.pdf.

17. Akin A, Bahar Ozvaris S, Özgülnar N, Dilbaz B, Gülersoy-Özaydin N. Üreme Sağlığına Giriş. T.C. Sağlık Bakanlığı Ana Çocuk Sağlığı ve Aile Planlaması Genel Müdürlügü. Ankara: 2005. ISBN: 975-590-132-9.

18. McMenamin M, Barry H, Lennon AM, Purcell H, Baum M, Keegan D, McDermott E, O'Donoghue D, Daly L, Mulcahy H. A survey of breast cancer awareness and knowledge in a Western population: lots oflight but little illumination. Eur J Cancer 2005; 41: 393-397. (PMID: 15691638) [CrossRef]

19. Najdyhor E, Krajewska-Kułak E, Krajewska-Ferishah K. Knowledge of women and men about breast cancer prevention. Ginekol Pol 2013; 84: 116-125. (PMID: 23668058) [CrossRef] 